\title{
NON-POLLEN PALYNOMORPHS AS ENVIRONMENTAL INDICATORS IN THE SURFACE SAMPLES FROM MANGROVE IN COSTA RICA
}

\author{
Svetlana Medeanic ${ }^{1}$, Natalia Zamora ${ }^{2 *}$ \& Iran C.S. Corrêa ${ }^{3}$ \\ ${ }^{1}$ Centro de Estudos de Geologia Costeira e Oceânica, Instituto de Geociências \\ - UFRGS, Bento Gonçalves ave., 9500. CP 15.001, Porto Alegre, RS, 91501-970 \\ ${ }^{2}$ Corresponding author, Programa de Pós-Graduação em Geociências, Instituto \\ de Geociências - UFRGS, Bento Gonçalves ave., 9500. CP 15.001, Porto \\ Alegre, RS, 91501-970 \\ ${ }^{3}$ Centro de Estudos de Geologia Costeira e Oceânica, Instituto de Geociências \\ - UFRGS, Bento Gonçalves ave., 9500, CP 15.001, Porto Alegre, RS, 91510-970 \\ *Autor para contacto: zamora14732@itc.nl
}

(Recibido: 25/02/08; aceptado: 12/12/08)

\begin{abstract}
Different organic walled non-pollen palynomorphs were identified from thirteen surface silty and sandy sediment samples in the southern part of Costa Rica, where mangroves are widespread. Non-pollen palynomorphs are numerous and diverse in comparison with the scarce pollen and spores of vascular plants. They are represented by dinoflagellate cysts, algal palynomorphs of Chlorophyta, cyanobacteria, fungal spores and hyphae, microforaminifers, scolecodonts and phytoliths. The most frequently represented are Botryococcus and microforaminifers whose frequencies change depending on the salinity of environments related to marine influence. Chlamydospores of the fungus Glomus are related with erosive processes. Cyanobacteria of the Rivularia-type may be connected to an increase in eutrophication by organic phosphate within an estuary. Non-pollen palynomorphs data are important as a palynological complement in the coastal regions of Costa Rica. Non-pollen palynomorphs are associated with pollen of Rhizophora, Lagencularia, Avicennia, Poaceae, Cyperaceae, and spores of various mangrove vegetation ferns.

Key words: Non-pollen palynomorphs, surface sediments, mangrove, estuary, Costa Rica.
\end{abstract}

RESUMEN: Diferentes palinomorfos no polínicos de paredes orgánicas, fueron identificados en trece muestras de sedimentos limosos y arenosos en la parte sur de Costa Rica, donde los manglares están ampliamente distribuidos. Los palinomorfos no polínicos son numerosos en comparación con la poca cantidad de polen y esporas de plantas vasculares. Están representados por cistos de dinoflagelados, palinomorfos de algas de Chlorophyta, cianobacterias, esporas de hongos e hifas, microforaminíferos, escolecodontos y fitolitos. Los más frecuentes son Botryococcus y microforaminíferos, cuya frecuencia es dependiente de la salinidad de ambientes influenciados por el mar. El palinomorfo Glomus puede ser un indicador de procesos erosivos. La cianobacteria tipo Rivularia puede estar ligada a una eutroficación del estuario. Datos sobre palinomorfos no polínicos están asociados con polen de Rhizophora, Lagencularia, Avicennia, Poaceae, Cyperaceae y esporas de varios pteridofitos característicos de la vegetación del manglar.

Palabras claves: Palinomorfos no polinícos, sedimentos superficiales, manglar, estuario, Costa Rica.

MEDEANIC, S., ZAMORA, N. \& CORREAA, I.C.S., 2008: Non-pollen palynomorphs as environmental indicators in the surface samples from mangrove in Costa Rica.- Rev. Geol. Amér. Central, 39: 27-51. 


\section{INTRODUCTION}

The mangrove ecosystems in the southern part of Costa Rica are important because their plants, principally trees and shrubs, prevent increases in soil salinity, erosion of the coastal plains and they are an essential source of food for different organisms. Pollen grains from sediments of different age are used as reliable indicators of past mangrove vegetation and may provide important data for palaeoecological and palaeoenvironmental reconstructions. According to Grindroad (1985), pollen that accumulates in mangrove has low mobility, seldom being redistributed by tides. Studies of the relationship between modern pollen from surface sediments and vegetation in mangrove swamps revealed that pollen and spores of terrestrial and aquatic vascular plants are not abundant (Jaramillo \& Bayoná, 2000; Horn, 1985; Rodgers III \& Horn, 1996; Zamora et al., 2007 a, b).

In addition to pollen and spores of vascular plants, surface sediment samples include different non-pollen palynomorphs (NPPs) which are organic-walled microfossils composed of sporopollenin-like or chitin (pseudochitin) polymers (Traverse, 1988). Often non-pollen palynomorphs are more resistant to corrosion and oxidation than pollen and spores, and they are not destroyed during chemical treatment of the samples for palynological analysis (van Geel, 1986; Guy-Ohlson, 1992; Rull \& Vegas-Vilarrúbia, 1999; Komârek \& Jankovská, 2001).

The study of NPPs started during the early 1970s in the Netherlands. Since that time, hundreds of morphological types of NPP were described and many of them have been identified. There is an increasing interest in the use of them for palaeoenvironmental reconstructions (van Geel, 2006; Prager et al., 2006, and Chmura et al., 2006), for evaluation of historical land use changes and exploring the ancient occupation in multiproxy study of the lake sediments (Riera et al., 2006; Argant et al., 2006).

In Costa Rica, one article has been recently published where microforaminers and scolecodonts were registered in Pliocene-Quaternary sediments (Zamora et al., 2007a). There are no studies on fossil and sub-fossil fungal palynomorphs in Costa Rica, but their use may be very productive for the mangrove where they are numerous and diverse. Corrigan (1986) described pollen assemblages for southern Costa Rica, but not really details of NNP. Important studies to understand the history of uplift and closure of the southern isthmus were made by Mc Dougall (1996) and Ibaraki (2002) using just foraminifers as proxies. Until recently, the NPPs have not been described as an important microfossil that may significantly help in environmental and palaeoenvironmental reconstructions.

In order to widely use NPPs for the environmental and palaeoreconstructions in Costa Rica, we decided to study them in the surface sediments of the present mangrove and surrounding areas from the different localities. The aim of the study is to present the preliminary data on NPPs acquired from an estuary system, and compare the different studied localities environmental characteristics along this section of the river and mangrove. Within these approaches, available literature on NPPs was used for their identifications and their environmental characteristics.

\section{THE STUDY AREA AND ITS ENVIRONMENT}

Costa Rica is located in the southern part of the Central American isthmus between the Pacific Ocean and the Caribbean Sea. Costa Rica is the part of an active margin where the Cocos plate subducts beneath the Caribbean plate with a rate of $9.0 \mathrm{~cm} / \mathrm{yr}$ (De Mets et al., 1994). The study was conducted in the eastern part of Osa Peninsula in southern Costa Rica (Fig. 1). This area lies within one of the most tectonically active areas of the region close to the interaction of three plates (Caribbean, Cocos, Nazca). High rates of uplift have been proposed in this region (Gardner et al., 1992) related to the subduction of the Cocos ridge. Pinter (1988) and Gardner et al. (1992) proposed for this area an uplift rate of $6.5 \mathrm{~mm} / \mathrm{yr}$. Some other regional models have been proposed to explain the complex tectonics and geologic characteristics of this area (Hey, 1977; Lonsdale \& Klitgord, 1978; Wilson \& Hey, 1981; Tournon, 1984; Barrit 

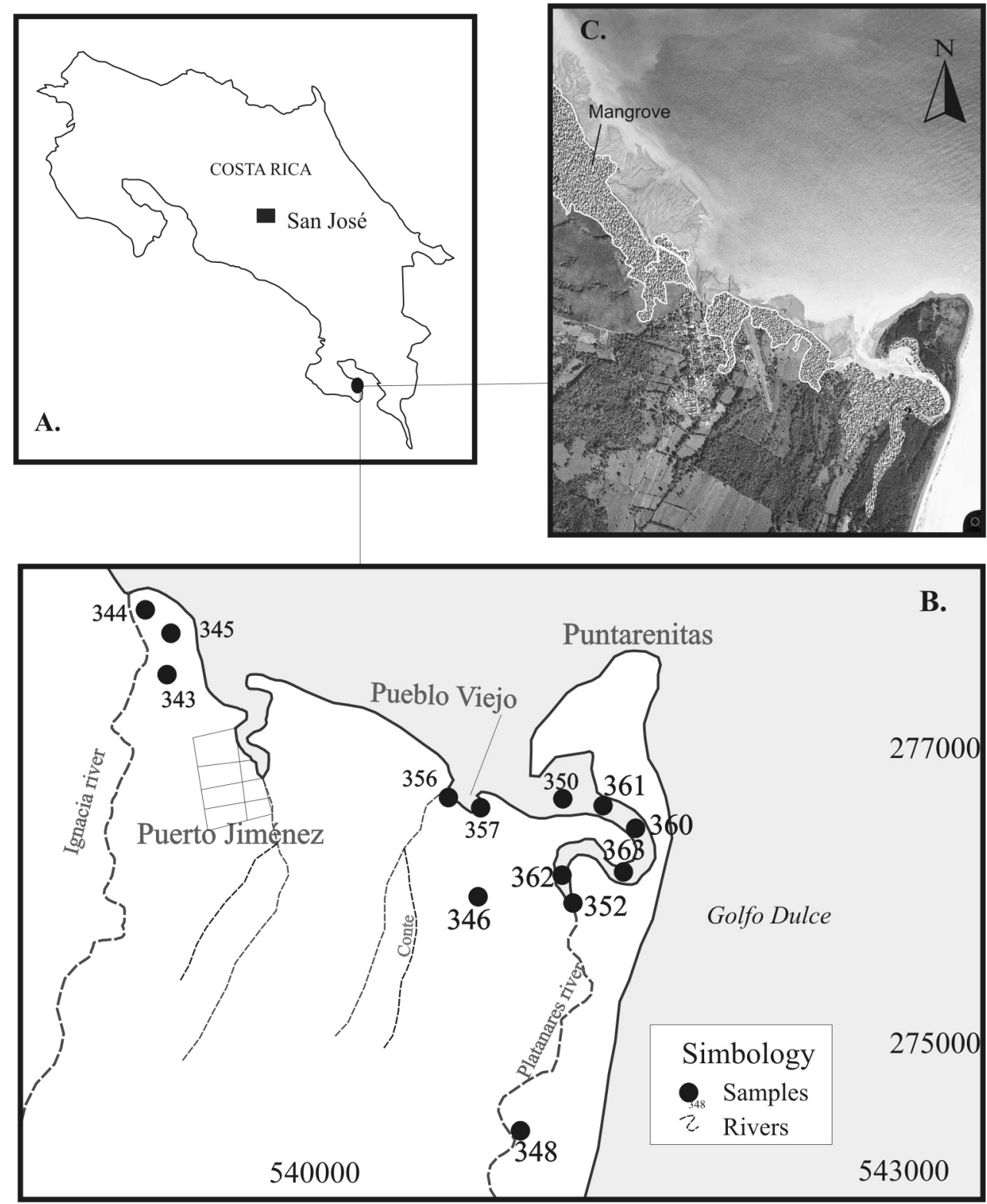

Fig. 1: Map of the studied area: A - regional map of Costa Rica; B - aerial photo (Terra 1998) where delimitation of mangrove is shown; C - the map showing sampling localities for palynological study.

\& Berrangé, 1987; Berrangé \& Thorpe, 1988; Di Marco 1994; Gardner et al., 1992; Vannucchi et al., 2006; Meschede et al., 1998; Meschede \& Barckhausen, 2001; Buchs, 2003).

The main outcrops, situated around of the studied mangroves are Pliocene-Quaternary deposits related with the Osa Group and Puerto Jiménez
Group. These deposits are overlying unconformably (Corrigan, 1986; Berrangé, 1989) the basement of the region (Tournon, 1984; Di Marco, 1994; Di Marco et al., 1995).

Osa Peninsula is characterized by a tropical climate (temperatures range between 21 and $31^{\circ} \mathrm{C}$ ). Precipitation varies between $4500-6500$ 
$\mathrm{mm} /$ year (Herrera, 1985). There are two distinctive seasons during the year: dry and rainy. Humidity is ranging between $75 \%$ and $90 \%$ respectively to the seasons. Three main rivers and some smaller drainage of the studied area flow into the Golfo Dulce. This gulf is described as a tropical fjord due to its morphology and depth (Richards et al., 1971; Quirós, 2003).

The mangrove development along sheltered tropical and subtropical coasts depends on seawater influence, tides, and freshwater inputs during heavy rains or storms (Blasco et al., 1996). Mangrove swamps spread along the Pacific Ocean coast are presently five genera characterizing them: red mangrove (Rhizophora), black mangrove (Avicennia), white mangrove (Languncularia), tea mangrove (Pellicieria rhizophorae) and button wood mangrove (Conocarpus erecta) (Simberloff, 1983). The present increased mangrove disturbance in Costa Rica and its consequent retrogradation is sometimes related to sea level changes; in some areas degradation may be linked to the expansion of cultivated plants, fruit-trees, some palms, Melina, coffee, cocoa, grasses and vegetable and herbaceous weeds. Development of pastures and extension of cropping may result an increased risk of mangrove disappearance.

\section{MATERIAL AND METHODS}

\section{Sampling}

Thirteen surface sediment samples were collected from the mangrove swamps at a depth between $0-5 \mathrm{~cm}$ (Fig. 1). The collected samples are represented predominantly by silt or sandy silt. The distance between sampling localities is about $0.2 \sim 0.5 \mathrm{~km}$. The samples were collected in the mangrove near the beach $(344,345,343,356$, and $357)$, at the bottom of the estuary $(350,363,360$, 363 , and 362), in the mouth of the Platanares river (352), in the limits of the mangrove area (346), and at the shore of the Platanares river (348). The collected samples were dried in an electric furnace at 60 o $C$. The dry samples were sieved $(D=200$ $\mu \mathrm{m})$ in order to remove plant remains.

\section{Chemical treatment}

The chemical treatment of the samples was performed according to Faegri \& Iversen (1975). The dry samples, $50 \mathrm{~g}$ in weight, were treated as follows: cold $\mathrm{HCl}(10 \%)$ and boiling $\mathrm{NaOH}(5 \%)$ for 15 minutes. Inorganic substances were separated from the organics by a dense liquid - a water solution of $\mathrm{ZnCl} 2$ (density $2.2 \mathrm{~g} / \mathrm{cm} 3$ ). The residual organics were mounted in glycerine-jelly to prepare the microscope slides.

The slides are stored in the Centro de Geologia Costeira e Oceânica (CECO) at the Institute of Geosciences, Federal University of Rio Grande do Sul, Brazil.

\section{General characteristic of principal NPP}

Here, we mention only the most representative NPPs encountered in the surface sediments of the mangroves in the studied area. Their characteristics are accompanied by wide bibliography references that may be useful for the future study of NPPs, both from the surface, and the Quaternary sediments in Costa Rica.

NPPs are widely distributed in the aquatic environments of the coastal plains. They are the zygospores, coenobiums and colonies of Chlorophyta (Cross et al., 1966; van Geel, 1976; van Geel \& van der Hammen, 1978; Pals et al., 1980) from freshwater environments, and may also be evidence of freshwater input into saline aquatic environments during pluvial periods (Medeanic, 2006 b).

Among the NPPs, there are dinoflagellate and acritarch cysts which are indicators for marine environments (sea water influence by tides and marine transgressions (Dale, 1976; Hoek et al., 1995; Grill \& Quattroccio, 1996).

Cyanobacteria are distributed in a wide range of habitats as free-living organisms, and as symbionts in terrestrial and aquatic environments. They are very sensitive to nutrient status of environments (Whitton \& Potes, 2000), and may serve as indicators for environmental changes. Their abundance may indicate an eutrophication, as a 
result of agricultural and domestic effluents enriched by phosphate (Knoja et al., 2007). Currently, cyanobacteria are rarely used for palaeoecological reconstructions due to their destruction resulting from attrition in the sediments or from the chemical treatment for palynological analysis. The palaeoecological value of heterocysts and akinetes in cyanobacteria has been reported by van Geel et al. (1994), Tomitani et al. (2006).

The microforaminifers represent chitinous inner tests of different benthic and planktonic foraminifers and are widely spread in the oceans and in the seas (Wilson \& Hoffmeister, 1952; van Veen, 1957; Pantic \& Bajaktarevic, 1988). Biological affinities of microforaminifers have not been established yet. The informal classification of microforaminifera is based on morphology, including number of chambers and the types of chambers arrangement (Stancliffe, 1989).

Chitinous fungal palynomorphs, resistant to destruction, are represented by ascospores, fruitbodies and hyphopodia (van Geel \& Aptroot, 2006). The importance of fossil fungal remains for palaeoenvironmental reconstructions has been reported in various publications (Elsik, 1976; Jarsen \& Elsik, 1986; van Geel, 1986; Pirozynski et al., 1988; Graf \& Chmura, 2006). Implications of fungal palynomorphs for the elevated salinity environments of the coastal plains existing during the Quaternary have not yet been sufficiently elaborated (Graf \& Chmura, 2006; Medeanic, 2006a; Limaye et al., 2007). The abundance and taxonomic variability of Glomus and its importance for dune stabilization was shown by Cordazzo \& Stümer (2007), who studied the distribution of Glomus in the roots of Panicum racemosum, the species that fixes and supports dunes. Limaye et al. (2007) registered an increase in Glomus in the sediments formed during the Late Glacial Period in India related to active erosion processes under a dry and continental climate.

Scolecodonts are the jaws of polychaete annelids. They are fossilized due to their chitinous teeth and dwelling tubes. According to Limaye et al. (2007), representative amounts of scolecodonts are important indicators of sediment deposition near the shelf or near the beaches.
Phytoliths are opal microscopic bodies of biogenic origin formed in the different part of plants (Geis, 1978; Barboni et al., 1999). They are an important tool for the recognition of palaeovegetation of the coastal plains whose species have a great number of silica-bodies and silicified epidermal cells (Lu \& Liu, 2003). For the tropical region, the application of phytoliths, especially cereals including Zea mays, may provide information about human activity in the region and agriculture development (Smithson, 1956; Bartlett et al., 1967; Kondo \& Sase, 1986; Piperno, 1989; Piperno et al., 1990; Fisher et al., 1995). The phytoliths have limited capacity to be transported and are indicators of local, rather than long-distance, input.

\section{RESULTS}

Most NPPs were identified after comparison with illustrations from the available literature. Their relative frequencies were based on a "total NPPs sum" and are shown in figure 2 and in table 1. The most frequent NPPs are represented in the Plates I-III. Palynological material in the residues was relatively abundant in NPPs, while pollen and spores of vascular plants were rare of even sporadic (figure 3, table 2). The order of samples is presented from a NW to SE trending profile.

A brief report on the characteristics of NPP and their occurrences in the surface sediments in southern Costa Rica is given below.

\section{Microalgae}

Microalgal palynomorphs are most frequent in many surface samples but their percentages differ depending on various factors such as salinity, influence of tides, rivers and freshwater inputs during heavy runoff, depth, and nutrient status. Microalgal palynomorphs are represented by dinoflagellate cysts and colonies and zygospores of Chlorophyceae and Zygnemataceae. 


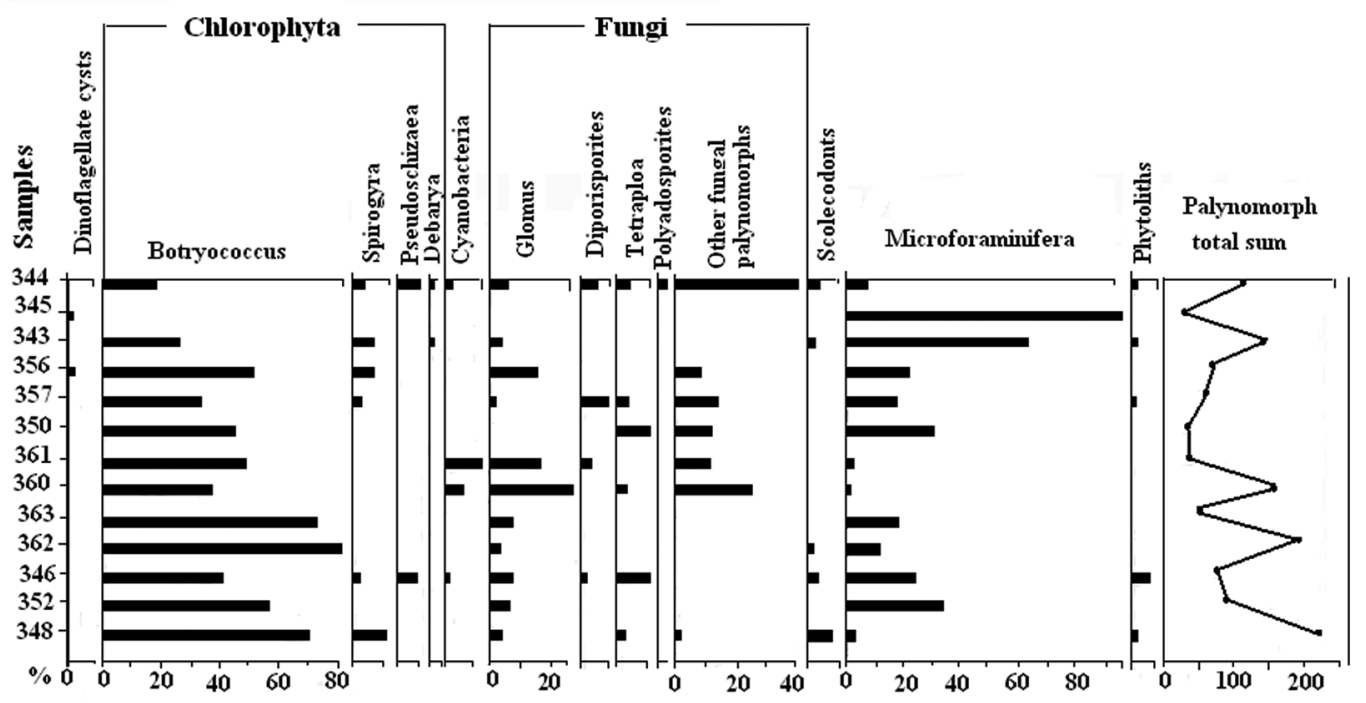

Fig. 2: Percentage palynodiagram of NPP from the surface samples in the southern part of Costa Rica.

\section{Dinoflagellate cysts}

In our samples, dinoflagellate cysts were rare and sporadic and poorly preserved. They were encountered only in the surface samples from the beach or near the beach $(345,356$, and 357$)$, where tidal influence is stronger than in other studied localities.

\section{Chlorophyceae - Botryococcus}

Colonies of Botryococcus (Plate I: 1) were recorded in most surface samples, except sample 345 , proving their distribution in the environments of elevated salinity of lagoons and salt and brackish-water marshes (Guy-Ohlson, 1992; Medeanic, 2006 a, b). The frequency of colonies is variable (Table 1, Fig. 2). The most abundant colonies are encountered in surface sediments $(348,362,363$, and 356), influenced by tides, and in the bottom surface sediments in the Platanares river, subjected to tidal influence (348).

\section{Zygnemataceae - Spirogyra}

The zygospores of Spirogyra (Plate I: 2, 3) do not exceed $11.2 \%$. The most frequent Spirogyra are encountered in high-salinity localities which obtain fresh water from the Ignacia river $(344,343)$, in the beach of Pueblo Viejo (346), and in the bottom of the Platanares river, influenced by tides (348).

\section{Zygnemataceae - Pseudoschizaea}

We encountered Pseudoschizaea (Plate I: 5) only in two samples at the localities subjected by the freshwater input of the Ignacia river (344) and the Platanares river (346).

\section{Cyanobacteria}

The encountered cyanobacteria are represented by Spirulina (Plate I: 6), Rivularia (Plate I: 7), and Anabaena? (Plate I: 10), only at localities characterized by some eutrophication due to sewage and domestic effluents (344). They were rarely encountered at the estuary $(360,361)$, where recurrent changes in salinity may have occurred and erosion processes are observed.

\section{Anabaena}

Filamentous cyanobacterium Anabaena is widely spread in tropical and subtropical regions 
Table 1

Non-pollen palynomorph taxa and their relative frequency (\%) from the surface samples of the Southern Costa Rica.

\begin{tabular}{|c|c|c|c|c|c|c|c|c|c|c|c|c|c|}
\hline \multirow{2}{*}{$\begin{array}{l}\text { Non-pollen palynomorph } \\
\text { taxa }\end{array}$} & \multicolumn{13}{|c|}{ Samples } \\
\hline & 344 & 345 & 343 & 356 & 357 & 350 & 361 & 360 & 363 & 362 & 346 & 352 & 348 \\
\hline \multicolumn{14}{|l|}{ Dinoflagellate } \\
\hline Cysts indet. & - & 2.4 & - & 2.5 & 1.3 & - & - & - & - & - & - & - & - \\
\hline \multicolumn{14}{|l|}{ Chlorophyta } \\
\hline Botryococcus & 18.3 & - & 24.3 & 50.0 & 32.5 & 43.5 & 46.5 & 37.6 & 72.7 & 82.3 & 40.5 & 58.3 & 70.0 \\
\hline Spirogyra & 4.2 & - & 5.8 & 5.0 & 2.5 & - & - & - & - & - & 2.5 & - & 11.7 \\
\hline Pseudoschizaea & 9.2 & - & - & - & - & - & - & - & - & - & 5.1 & - & - \\
\hline Debarya & 1.4 & - & 1.1 & - & - & - & - & - & - & - & - & - & - \\
\hline \multicolumn{14}{|l|}{ Cyanobacteria } \\
\hline Anabaena & - & - & - & - & - & - & - & 2.1 & - & - & - & - & - \\
\hline Spirulina & 0.7 & - & - & - & - & - & - & 1.6 & - & - & 2.5 & - & - \\
\hline Rivularia & 1.4 & - & - & - & - & - & 14.0 & - & - & - & - & - & - \\
\hline \multicolumn{14}{|l|}{ Fungal palynomorphs } \\
\hline Glomus & 5.0 & - & 3.7 & 10.0 & 1.3 & - & 18.6 & 29.5 & 9.1 & 4.1 & 7.6 & 7.8 & 4.6 \\
\hline Diporisporites & 3.5 & - & - & - & 10.0 & - & 4.6 & - & - & - & 2.5 & - & - \\
\hline Tetraploa & 2.8 & - & - & - & 1.3 & 8.7 & - & 1.3 & - & - & 10.1 & - & 2.3 \\
\hline Polyadosporites & 2.8 & - & - & - & - & - & - & - & - & - & - & - & - \\
\hline Type A & 7.0 & - & - & - & 7.5 & - & - & 0.5 & - & - & - & - & - \\
\hline Type B & - & - & - & - & 7.5 & 13.0 & 10.0 & 15.9 & - & - & - & - & - \\
\hline Hyphae & 33.1 & - & - & 10.0 & 10.0 & - & 4.0 & 6.3 & - & - & - & - & 0.9 \\
\hline Other indet. & - & - & - & - & 6.2 & 4.3 & - & 2.1 & - & - & - & - & - \\
\hline Phytoliths & 1.4 & - & 2.1 & - & 2.5 & - & - & - & - & - & 5.1 & - & 2.3 \\
\hline Scolecodonts & 1.4 & - & 10.5 & - & - & - & - & - & - & 0.8 & 2.5 & - & 7.0 \\
\hline Microforaminifera & 7.7 & 97.6 & 62.4 & 22.5 & 17.5 & 30.4 & 2.3 & 3.2 & 18.2 & 12.8 & 21.5 & 34.0 & 1.2 \\
\hline Total sum & 142 & 41 & 189 & 80 & 80 & 46 & 43 & 189 & 55 & 243 & 79 & 103 & 257 \\
\hline
\end{tabular}

in eutrophic alkaline freshwater and salt lakes. It is represented by free floating trichomes with heterocysts intercalated and akinetes (Van Geel et al., 1994; Komârek \& Komarková-Legnerová, 2002). Filaments resembling Anabaena were found only in one surface sample (360) in the bottom of the estuary (Plate I: 8).

\section{Rivularia}

Identifications of colonies of Rivularia sheet were made according to recently published article of Limaye et al. (2007). According to Knoja et al. (2007), Rivularia colonies occur in apparently very different habitat, including the marine littoral, lakes, ponds, and even fast flowing streams where organic phosphate is presumably available. Colonies of sheets of Rivularia (Plate I: 7) were encountered in two samples. Rare colonies of Rivularia sheets were encountered in a locality near the beach, adjacent to a farm (344), where domestic and agricultural effluents are mixed with the surface water. Frequent colonies of sheets of Rivularia were recorded in the surface sample from the bottom of the estuary (361), characterized by recurring changes in salinity and eutrophication by domestic effluents, probably, 


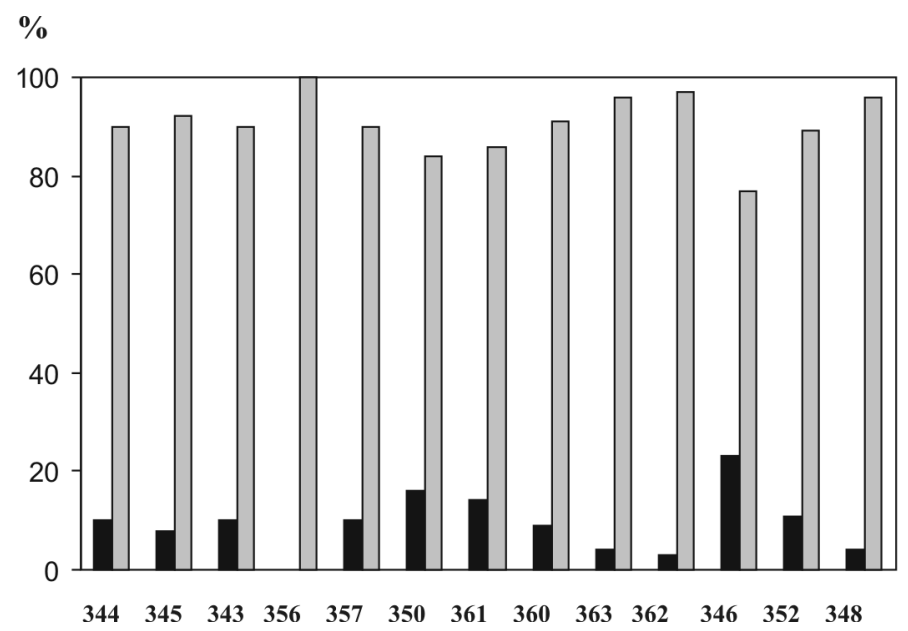

Fig. 3: Percentage diagram of relationship between pollen and spores of vascular plants (columns in black) and NPP (columns in gray) from the surface samples in the southern part of Costa Rica: axis $\mathrm{x}$ - number of the samples, $\mathrm{y}$ - percentage.

rich in phosphate. We do not exclude that the cyanobacteria occurrences could be the result of lowoxygen environment conditions, even in shallow areas of the estuary (Berrangé, 1987), or in deep anoxic areas (Svendsen et al., 2006).

\section{Spirulina}

We encountered spiral trichomes of Spirulina in the surface sediments from mangrove (346) and in other samples together with Rivularia (344), and Anabaena? (360).

\section{Fungal palynomorphs}

We found a great number and a wide diversity of fungal spores and hyphae, varying from unicellular to multicellular. Some fungal spores have a very distinctive morphology and some of them may be easily identified. The most frequent are Glomus, Polyadosporites, Tetraploa and Diporisporites. Some relatively frequent fungal spores (Type $A$ and Type B) were not identified and their biological affinities were not established. Abundant fungal spores and hyphae in some localities may be related to their transport by freshwater input from adjacent mangroves.

\section{Glomus}

Chlamydospores of Glomus were encountered practically in all studied samples (Plate II: 1-3). Glomus was most abundant in the surface sediments in the estuary (361 and 360) around which erosive processes are actually evident. Insignificant quantities of Glomus were found in samples 350 and 345 , and lowest quantities were encountered in 343, 362 and 357.

\section{Diporisporites}

Rare and sporadic spores of Diporisporites (Plate II: 4) were encountered in surface samples characterized by major frequencies of fungal palynomorphs (Table 1, Fig. 2).

\section{Polyadosporites}

Registered Polyadosporites correspond to multicelled teliospores of Ravenelia, parasiting on Fabaceae, and distributed predominantly in the Neotropics (Hernández et al., 2007). Teliospores of Ravenelia arecloselyresembled toPolyadosporites, found in the surface sediments in the gallery forest of Paraná River in Brazil (Medeanic et al., 2004). In studied surface sediments, Polyadosporites was 
Table 2

Pollen and spore taxa and their presence (+), absence (-) from the surface samples of the Southern Costa Rica .

\begin{tabular}{|c|c|c|c|c|c|c|c|c|c|c|c|c|c|}
\hline \multirow{2}{*}{ Pollen and spore taxa } & \multicolumn{13}{|c|}{ Samples } \\
\hline & 344 & 345 & 343 & 356 & 357 & 350 & 361 & 360 & 363 & 362 & 346 & 352 & 348 \\
\hline \multicolumn{14}{|l|}{ MAGNOLIOPHYTA } \\
\hline Alchornea & + & - & + & - & - & - & - & - & - & - & - & - & - \\
\hline Alnus & - & - & - & - & - & - & - & - & - & - & + & - & - \\
\hline Apiaceae & + & - & - & - & - & - & - & - & - & - & - & - & - \\
\hline Asteraceae & + & - & + & - & - & + & - & + & - & - & + & - & - \\
\hline Avicennia & - & - & + & - & - & - & - & - & - & - & - & - & - \\
\hline Brassicaceae & - & - & - & - & - & - & - & - & - & - & + & - & - \\
\hline Bursenaceae & - & - & + & - & - & - & - & - & - & - & + & - & - \\
\hline Carya & + & - & - & - & - & - & - & + & - & - & + & - & - \\
\hline Cecropia & - & - & + & - & + & + & + & + & - & + & + & - & - \\
\hline Chenopodiaceae & - & - & - & - & - & - & - & - & - & - & + & + & - \\
\hline Convolvulaceae & - & - & + & - & - & - & - & - & - & - & - & - & - \\
\hline Cordia & - & - & + & - & - & - & - & - & - & - & - & - & - \\
\hline Cyperaceae & + & - & + & - & + & + & + & - & - & + & + & - & - \\
\hline Juncaginaceae & + & - & + & - & - & - & - & - & - & - & - & - & - \\
\hline Fabaceae & + & - & - & - & - & - & - & - & - & - & - & - & - \\
\hline Languncularia & - & - & + & - & - & - & - & - & - & - & + & - & + \\
\hline Malvaceae & + & - & + & - & - & - & - & - & - & - & - & - & - \\
\hline Urticacaceae & + & - & + & - & + & + & + & + & - & + & + & + & - \\
\hline Palmae & - & - & - & - & - & - & + & - & - & - & + & + & - \\
\hline Piperaceae & + & + & + & - & + & - & - & - & - & - & + & - & + \\
\hline Plantaginaceae & - & - & + & - & - & - & - & - & - & - & - & - & - \\
\hline Poaceae & + & - & + & - & + & + & + & + & - & + & + & + & + \\
\hline $\begin{array}{l}\text { Polygonum } \\
\text { hydropiperoides }\end{array}$ & + & - & - & - & - & - & - & - & - & - & - & + & - \\
\hline Rhizophora & - & - & + & - & + & + & + & + & + & + & + & - & - \\
\hline Scrophulariaceae & - & - & + & - & + & - & - & - & - & - & - & - & - \\
\hline Solanaceae & - & - & - & - & - & - & - & - & - & - & + & - & - \\
\hline Typhaceae & - & - & - & - & + & - & - & - & - & - & - & - & - \\
\hline Ulmaceae & + & - & + & - & - & - & - & - & - & - & + & - & - \\
\hline PTERIDOPHYTA & & & & & & & & & - & & & & \\
\hline Azolla & - & - & - & - & - & - & - & + & - & - & + & - & + \\
\hline Alsophyla & - & - & - & - & - & + & - & - & - & - & + & + & + \\
\hline Cyathaceae & + & - & + & - & + & - & + & + & - & + & + & - & - \\
\hline Dicksonia & - & - & - & - & - & - & - & - & - & - & + & - & - \\
\hline Dryopteris & - & - & - & - & - & + & - & - & - & - & + & - & - \\
\hline Microgramma & - & - & + & - & - & - & - & + & - & - & - & - & - \\
\hline Osmunda & - & - & - & - & - & + & - & - & - & - & + & + & + \\
\hline
\end{tabular}


Table 2 (continuation)

Pollen and spore taxa and their presence (+), absence (-) from the surface samples of the Southern Costa Rica .

\begin{tabular}{|c|c|c|c|c|c|c|c|c|c|c|c|c|c|}
\hline \multirow{2}{*}{ Pollen and spore taxa } & \multicolumn{13}{|c|}{ Samples } \\
\hline & 344 & 345 & 343 & 356 & 357 & 350 & 361 & 360 & 363 & 362 & 346 & 352 & 348 \\
\hline \multicolumn{14}{|l|}{ PTERIDOPHYTA } \\
\hline Polypodiaceae & + & - & + & - & + & + & - & - & + & - & + & + & + \\
\hline Pteridae & - & - & - & - & - & - & - & + & + & + & + & + & + \\
\hline Salvinia & - & - & - & - & - & - & - & - & - & - & - & - & + \\
\hline Total sum of taxa & 15 & 1 & 21 & 0 & 10 & 10 & 7 & 10 & 3 & 7 & 24 & 9 & 9 \\
\hline
\end{tabular}

registered only in one surface sample (344), in the locality of the Ignacia river confluence (Plate II: 7). These teliospores may have been transported by rivers from the adjacent forested areas. Other sources may be connected with agricultural activities of farmers who plant fruit trees and vegetables on their land (situated near the locality of sampling) that are favourable for these fungi.

\section{Tetraploa}

Little is known about the biology and distribution of Tetraploa, although their fossil and subfossil records are common in the sediments of coastal plains subjected to sea-water input. Spores of Tetraploa are common in the sediments of coastal plain environments of elevated salinity, such as mangrove (Rull \& Vegas-Vilarrúbia, 1999) and salt-and-brackish-water marshes (Medeanic, 2006a; Medeanic et al., 2007). The most frequent spores of Tetraploa were registered in the mangrove (346), where relatively rich pollen-and-spore assemblage was defined (Table 2, Plate II: 8-9). Tetraploa was frequently recorded in the surface sediments at the bottom of the estuary (350), surrounded by mangroves. In general terms, it was not encountered in areas of stronger influence of tides $(345,343$, and 356$)$.

\section{Other fungal spores}

Fungal palynomorphs of Type A (Plate II: 56) and Type $B$ (Plate II: 10) were most frequent in the sample 344 , in the locality of the Ignacia river confluence. It is hypothesized that these spores were transported by a river from the forested areas where the diversity of fungi may be higher than in the mangrove swamps. Another explanation of the high frequency of these fungi may be related to fruit-tree and vegetable planting in the surrounding areas.

\section{Hyphae}

The most abundant hyphae are encountered in locality 344 (Plate II: 11), where there is significant freshwater input from the Ignacia river. Notable frequencies of hyphae are observed in localities 356 and 357, influenced by the freshwater influxes of the small drainage Pueblo Viejo. The hyphae are predominant in the surface sediments of these sites which are subject to significant rivers and temporal freshwater inputs during strong pluvial periods. They are rare in the estuary samples, and are absent in the most of other samples (Table 1, Fig. 2).

\section{Vegetative remains}

\section{Phytoliths}

Microscopic silica bodies and silicified epidermal cells of grasses composed of opal are sporadic and are relatively rare in the surface samples near the beach (344 and 357), in mangrove (346), and at the shore of Platanares river (348). They are represented by different morphological types. The most frequent phytoliths are elongate 
Table 3

Non-pollen palynomorphs from the surface sediments of the Southern Costa Rica the coast and palaeoecological implications

\begin{tabular}{|c|c|c|c|}
\hline Non-pollen palynomorphs & Morphology characteristic & Distribution & $\begin{array}{l}\text { Palaeoecological } \\
\text { implications }\end{array}$ \\
\hline \multicolumn{4}{|l|}{ Microalgae } \\
\hline Dinoflagellate cysts & $\begin{array}{l}\text { Various ornamentation organ- } \\
\text { ic-walled marine microflora } \\
\text { (cysts), } 40-70 \mu \mathrm{m} \text { in diameter }\end{array}$ & The oceans and the seas & $\begin{array}{l}\text { Marine influence (transgres- } \\
\text { sions) and the coastal plains un- } \\
\text { der sea water influence (tides) }\end{array}$ \\
\hline Botryococcus & $\begin{array}{l}\text { Colonial green algae, } 10-80 \\
\mu \mathrm{m} \text { in diameter }\end{array}$ & $\begin{array}{l}\text { Freshwater-brackish water } \\
\text { environments }\end{array}$ & $\begin{array}{l}\text { Brackish-water environments } \\
\text { (mangrove, lagoon, intertidal } \\
\text { marshes) }\end{array}$ \\
\hline Spirogyra & $\begin{array}{l}\text { Green algae oval, ellipsoidal } \\
\text { zygospores } 20-30 \times 15-68 \mu \mathrm{m} \\
\text { in diameters }\end{array}$ & $\begin{array}{l}\text { Freshwater fluvial, lacustrine } \\
\text { environments }\end{array}$ & $\begin{array}{l}\text { Significant freshwater input into } \\
\text { intertidal marshes or mangrove }\end{array}$ \\
\hline Debarya & $\begin{array}{l}\text { Green algae zygospores } 35- \\
48 \mu \mathrm{m} \text { in diameter }\end{array}$ & $\begin{array}{l}\text { Freshwater fluvial, lacustrine } \\
\text { environments }\end{array}$ & $\begin{array}{l}\text { Significant freshwater input } \\
\text { into intertidal marshes or } \\
\text { mangrove }\end{array}$ \\
\hline Pseudoschizaea & $\begin{array}{l}\text { Green algae (zygnemataceous) zy- } \\
\text { gospores, } 35-50 \mu \mathrm{m} \text { in diameter }\end{array}$ & $\begin{array}{l}\text { Grow at the edge of streem } \\
\text { and in the ponds }\end{array}$ & $\begin{array}{l}\text { Freshwater input (rivers) into } \\
\text { intertidal marshes }\end{array}$ \\
\hline \multicolumn{4}{|l|}{ Cyanobacteria } \\
\hline Rivularia & $\begin{array}{l}\text { Colonial blue-green algae } \\
\text { (heterocysts and trichomes) } \\
40-95 \mu \mathrm{m} \text { in diameter }\end{array}$ & Brackish-water environments & $\begin{array}{l}\text { Eutrofication of aquatic envi- } \\
\text { ronments or reccurred chang- } \\
\text { es in saliny in estuary }\end{array}$ \\
\hline \multicolumn{4}{|l|}{ Fungi } \\
\hline Glomus & $\begin{array}{l}\text { Spores varying in size } 30-75 \\
\mu \mathrm{m} \text { in diameter, usually with } \\
\text { hyphae attachment }\end{array}$ & $\begin{array}{l}\text { Coastal plains, in principal } \\
\text { plant that fix and support } \\
\text { dunes dunes, salt matshes }\end{array}$ & $\begin{array}{l}\text { Indicator of erosion around } \\
\text { the area, vast distribution in } \\
\text { coastal plains }\end{array}$ \\
\hline Tetraploa & $\begin{array}{l}\text { Spores with four appendices, } \\
35-60 \mu \mathrm{m} \text { in diameter }\end{array}$ & $\begin{array}{l}\text { Sporadically in salt and } \\
\text { brackish-water marshes and } \\
\text { mangrove }\end{array}$ & $\begin{array}{l}\text { Salt and brackish-water } \\
\text { marshes and mangrov }\end{array}$ \\
\hline $\begin{array}{l}\text { Polyadosporites (biological } \\
\text { affinities - Ravenelia) }\end{array}$ & $\begin{array}{l}\text { Fungal multicelled teliospores } \\
\text { with smooth outer layer, 90- } \\
100 \mu \mathrm{m} \text { in diameter }\end{array}$ & $\begin{array}{l}\text { Warm and tropical climate of } \\
\text { Neotropic where Fabaceae } \\
\text { species are abundant }\end{array}$ & $\begin{array}{l}\text { Coastal plains subjected by } \\
\text { freshwater input; may indi- } \\
\text { cated on cultivated plants }\end{array}$ \\
\hline Hyphae & $\begin{array}{l}\text { Chitinous unicelular to mul- } \\
\text { ticelular dichotomously } \\
\text { branched }\end{array}$ & $\begin{array}{l}\text { Numerous hyphae in organic } \\
\text { rich sediments }\end{array}$ & $\begin{array}{l}\text { Indicative of humid and warm } \\
\text { climate, freshwater input dur- } \\
\text { ing pluvial periods and trans- } \\
\text { port by rivers }\end{array}$ \\
\hline Phytoliths & $\begin{array}{l}\text { Different morphological types } \\
\text { of biogenic siliceous micro- } \\
\text { scopic bodies and mineralized } \\
\text { epidermal casts }\end{array}$ & $\begin{array}{l}\text { Different terrestrial ecosys- } \\
\text { tems where grasses predomi- } \\
\text { nate }\end{array}$ & $\begin{array}{l}\text { Indicators of plant-taxa and } \\
\text { relative vegetation cover den- } \\
\text { sity (especially, in Poaceae, } \\
\text { Cyperaceae and Palmae) }\end{array}$ \\
\hline Scolecodonts & $\begin{array}{l}\text { Chitinous mouth part of an- } \\
\text { nelid predominantly marine } \\
\text { worms in form of jaws and } \\
\text { maxillae, } 80-200 \mu \mathrm{m}\end{array}$ & $\begin{array}{l}\text { Salt marshes, mangrovs and } \\
\text { beaches }\end{array}$ & $\begin{array}{l}\text { Indicators of shallow water } \\
\text { basins near the beaches }\end{array}$ \\
\hline Microforaminifera & $\begin{array}{l}\text { Coiled plani-and-trochospiral } \\
\text { chitinous inner tests of juve- } \\
\text { nile foraminifera, } 40-150 \mu \mathrm{m} \\
\text { in diameter }\end{array}$ & Oceans and seas & $\begin{array}{l}\text { Sea water incursions of tides } \\
\text { or sea-level oscillations } \\
\text { (transgressions), the most fre- } \\
\text { quent in the surface sediments } \\
\text { near sea shore and in estuary }\end{array}$ \\
\hline
\end{tabular}


(Poaceae, Plate III: 1). Phytoliths of Palmae type are circular crenate (Plate III: 2, 3). Sporadic frequency phytolits have dumbbell contours (Plate III: 4), and phytoliths of roundel shape are rare (Plate III: 5), both of these type belong to Panicoid phytoliths of Poaceae.

\section{Charcoal particles}

Charcoal particles were extremely rare in studied samples. Their low frequency may indicate a low incidence of fire generated by anthropogenic causes in the region.

\section{Invertebrates}

\section{Scolecodonts}

In our samples, scolecodonts are relatively rare (Plate III: 6-7). They are encountered in the palynological slides from different localities near the beach (344, 343 and 362), in mangrove swamp (346) and one locality, situated not far from the beach (348). They are associated with microforaminifers, some indefinite chitinous parts of arthropods, and other palynomorphs (Fig. 2, Table 1). They are not observed in the surface sediments at the bottom of the estuary which may indicate on their low capacity for transport.

\section{Microforaminifera}

In most samples, microforaminifers are more frequent than other palynomorphs (Fig. 2). Many of them are diverse in morphology and in size. The planispiral and trochospiral type forms, resembling Globigerina-type, are common (Plate III: 8-9). In some samples, microforaminifers of a single chamber type are rare. The preservation of the microforaminifers is directly related to deposition processes. Poor preservation may be the result of redeposition the sediments by different reasons (heavy rain-off, tides, marine transgressions and by other unpredictable reasons). Some samples have a poor preservation that may be indicative of sedimentary conditions. High frequencies of microforaminifers are encountered in surface samples from localities near the beach (343 and 345), and in samples from the estuary bottom (350 and 352). The frequencies of microforaminifers decrease closer to the beach, in areas influenced by rivers (344 and 356), and in the estuary with freshwater input $(361,360,363$, and 362). A few microforaminifers were encountered in the surface sample of mangrove swamp near the estuary (346). Microforaminifers are rarely observed in the beach (357), and at the locality, subjected by domestic effluents from the houses of the Pueblo Viejo community. Microforaminifers are low-frequent in mangrove situated relatively far from the estuary where tidal influence is insignificant, and the influence of the Platanares river is strong.

\section{DISCUSSION}

The value of the encountered NPPs for paleoecological reconstructions is summarized in the Table 3, where identified taxa of palynomorphs are mentioned, as well as morphological and ecological characteristics, and implications for environmental reconstructions. This table may serve as practical guide, helping in their interpretation. Not all NPPs were identified and we hope that in the future they will be identified and described, as well as their usage. This endeavor will progress as more data is gathered and contribute to World Bank Data on NPPs. Generalizing our results, we propose that in the different localities of the studied mangrove swamp areas, the NPPs are differentiated by taxa frequency and diversity, and their abundance, depending on environmental characteristics. In most of the samples, the microforaminifers and Botryococcus are predominant, indicating permanently elevated salinity environments. The localities, situated closely to marine influence (principally, by tides) are characterized by presence of marine indicators, such as dinoflagellate cysts and a few frequencies of freshwater algal palynomorphs. On the contrary, in the samples of the localities situated relatively far from marine influence, the frequent freshwater algal palynomorphs are encountered. The presence of cyanobacteria may be the result of domestic effluence leading to eutrofication with 
phosphate enrichment (Rivularia). The samples, most diverse and rich in NPPs, are from the localities influenced by rivers.

Below, the characteristics of NPPs assemblages from the different localities are given.

The samples from the beach are characterized by notable frequencies of microforaminifers, Botryococcus and fungal palynomorphs, rare phytoliths and scolecodonts. Dinoflagellate cysts - sporadic and rare, probably, due to poor preservation, are the most probably transported by tides and/or may have been redeposited.

In localities of freshwater inputs by rivers into the mangrove swamps, the taxonomic variety of NPPs significantly increases (especially, fungal palynomorphs, some freshwater zygospores of Spirogyra and Pseudoschizaea). They are associated with relatively rare pollen and spores of vascular plants, where indicative for mangrove vegetation - Rhizophora, Avicennia, Cecropia, Urticales, Alchornea, Piperaceae, Poaceae, Cyperaceae and rare spores of some ferns were encountered.

The samples from the bottom of the estuary are similar to the samples located closely to the beach, because of the predominance of Botryococcus and microforaminifers, sporadic Tetraploa and rare scolecodonts. Nevertheless they are differenctiated by a complete absense of freshwater algal palynomorphs and a notable abundance of Glomus (as a result of soil erosion in the surrounding areas), and other fungal palynomorphs (Types A and B). The presence of cyanobacteria is probably linked to eutrophication. Pollen and spores of vascular plants are rare, represented by Rhizophora, Poaceae, Cyperaceae, Asteraceae and Urticales. Spores of the aquatic fern Azolla were encountered in just one sample, characterizing mangrove swamp vegetation.

The samples from the bottom and shore of the Platanares river, where salinity considerably decreases are characterized by a significant decline in microforaminifers and fungal palynomorphs. Colonies of Botryococcus predominate, and the frequencies of Spirogyra, scolecodonts and indefinite chitin parts of Arthropoda increase. Rare pollen of Piperaceae, Poaceae and sporadic spores of Azolla, Alsophyla, Osmunda, Polypodiaceae, Pteridae, and Salvinia may indicate a relatively low salinity.
The samples from the main mangrove area are characterized by notable frequencies of Botryococcus and microforaminifers, Tetraploa, rare Spirogyra and Pseudoschizaea, scolecodonts and phytoliths. They are associated with pollen, characterized mangroves, such as Avicennia, Bursenaceae, Cecropia, Urticales, Piperaceae, Poaceae, and Rhizophora.

The samples from the bottom of the Platanares river are characterized by lower quantities of NPPs. Probably, an anoxic environment was created due to the capacity of mangrove plants to block water flow. The higher quantities of NPPs were found at localities with more energy of the river and with greater freshwater input or rivers' entrance.

\section{CONCLUSIONS}

NPP assemblages from the surface sediments in southern Costa Rica mangroves are reported for the first time. Palynological data obtained from the surface samples show relatively low frequencies of pollen and spores, but abundant and diverse NPPs. This fact reinforced us to perform an analysis of their distribution at the different localities, taking into account ecological characteristics and patterns mentioned in the published articles. We used a great number of useful bibliographies which were helpful in determining NPP implications for environmental characterization.

This work has focused on surface samples of an estuarine environment and the obtained results show information related to dynamics and occurring processes in these environments. They may serve as important tools for understanding tectonic history of uplift and subsidence with further studies and possibility of dating. Thus, the implications of NPPs are very useful for palaeogeographic reconstructions in dynamic areas, such as the geological setting of Costa Rica.

The different NPPs may serve as valuable indicators for the evaluation of rapid changes in mangrove environments, and therefore the comparison with the spatial distribution of different NPPs in the mangrove in the present is useful. 
Tectonic events could influence NPPs preservations, but those composed of chitin (fungal palynomorphs, microforaminifers and scolecodonts) may continue to be preserved in sediments, recording past sedimentation conditions.

NPPs are certainly may be useful for palaeoecological reconstructions of coastal environments influenced by sea level oscillations, drainage river system and climatic changes and tectonic.

Implications of all above mentioned palynomorphs can lead to general and detailed palynological conclusions about past environments of coastal plains. Further research of NPPs may significantly contribute for interpretations based on pollen and spores and assist in improving detailed palynological conclusions.

\section{ACKNOWLEDGEMENTS}

We thank the Conselho Nacional de Desenvolvimento Científico e Tecnológico (CNPq) for the grants (300005/2007-5 and 302926/2004-6) and the Comisión Nacional de Prevención de Riesgos y Atención de Emergencias (CNE, Costa Rica) for the assistance with the logistic of transportation to the area as part of the master project in coastal evolution. We are very grateful to Dr. Bas van Geel (The Netherlands) for his careful corrections of the manuscript text and identifications of some taxa. We thank to Dr. J.S. Carrión García (Spain) for his useful suggestions. We appreciate help of Dr. J.A. López Sáez (Spain) for his constructive critics and suggestions for manuscript improvement. Special thanks to Gerardo J. Soto for the important recommendations and suggestions for this manuscript.

\section{REFERENCES}

ARGANT, J., LÓPEZ-SÁEZ, J.A. \& BINTZ, P., 2006: Exploring the ancient occupation of a high altitude site (Lake Lauzon, France): Comparison between pollen and non-pollen palynomorphs.- Review of Palaeobotany and Palynology, 141(1-2): 151-163.
BARBONI,D.,BONNEFILLE, R.,ALEXANDRE,

A. \& MEUNIER, J.D., 1999: Phytoliths as paleoenvironmental indicators, West Side Middle Awash Valley, Ethiopia.Palaeogeography, Palaeoclimatology, Palaeoecology, 152: 87-100.

BARRIT, S. \& BERRANGÉ, J.P., 1987: Interpretation of a gravity survey of the Osa Península and environments, southern Costa Rica.- Overseas Geol. \& Miner. Resour. 64: 1-19.

BARTLETT, A.S., BARGHOOM, E.S. \& BERGER, R., 1967: Fossil opal maize from Panama.- Science, 165 (3891): 389.

BERRANGE, J.P., 1987: Gas Seeps on the margins of the Golfo Dulce pull-apart basin, southern Costa Rica.- Rev. Geol. Amér. Central, 6: 103-111.

BERRANGÉ, J., 1989: The Osa Group: An auriferous Pliocene sedimentary unit from the Osa peninsula, Southern Costa Rica. - Rev. Geol. Amér. Central, 10: 67-93.

BERRANGÉ, J.P. \& THORPE, R.S., 1988: The geology, geochemistry and emplacement of the Cretaceous-Tertiary ophiolitic Nicoya Complex of the Osa Peninsula, Southern Costa Rica.- Tectonophysics, 147: 193-220.

BLASCO, F., SAENGER, P. \& JANODET, E., 1996: Mangrove as indicators of coastal change.- Catena, 27: 167-178.

BUCHS, D. M., 2003: Etude géologique et géochimique de la région du Golfo Dulce (Costa Rica). Genese et évolution d'eédifices océaniques accretés a la marge de la plaque Caraibe.127 págs. Institute de Geologie. University of Lausanne, Switzerland. [Thesis M.Sc.].

BUCHS, D.M. \& BAUMGARTNER, P.O., 2007: Comment on "From seamount accretion to tectonic erosion: Formation of Osa Mélange and the effects of Cocos Ridge 
subduction in southern Costa Rica".Tectonics, 26, TC3009.

CHMURA, G.L., STONE, P.A. \& ROSS, M.S., 2006: Non-pollen microfossils in Everglades sediments. - Rev. Palaeobot. Palynol. 141(1-2): 103-120.

CORDAZZO, C.V. \& STÜMER, S.L., 2007: Ocorrência de fungos micorrízicos arbusculares em Panicum racemosum (P.Beav.) Spreng (Poaceae) em dunas costeiras do extremo sul do Brasil.- Atlântica, Rio Grande, 29(1): 65-68.

CORRIGAN, J.D., 1986: Geology of the Burica Peninsula, Panamá - Costa Rica: neotectonic implications for the southern middle America convergent margin.- 152 págs. Univ. Austin, Texas. [Thesis M.Sc.].

CORRIGAN, J., MANN, P. \& INGLE, J.C., 1995: Forearc response to subduction of the Cocos Ridge, Panama-Costa Rica.- Geol. Soc. Am. Bull., 102: 628-652.

CROSS, A.T., THOMPSON, G.G. \& ZAITZEFF, J.B., 1966: Source and distribution of palynomorphs in bottom sediments, southern part of the Gulf of California.- Marine Geology, 4: 467-524.

DALE, B., 1976: Cyst formation, sedimentation and preservation: factors affecting Dinoflagellate assemblages in recent sediments from Trondheims fjord, Norway.Rev. Palaeobot. Palynol. 22(1): 39-60.

DENYER, P., BAUMGARTNER P. O \& GAZEL, E., 2006: Characterization and tectonic implications of Mesozoic-Cenozoic oceanic assemblages of Costa Rica and western Panama.- Geol. Acta, 4: 219-235.

DE METS, C., GORDON, R.G., ARGUS, D.F. \& STEIN, S., 1994: Effect of recent revisions to the geomagnetic reversal time scale on estimates of current plate motions.Geophys. Res. Lett. 21: 2191-2194.
DI MARCO, G., 1994: Les terrains accretés du sud du Costa Rica. Évolution tectonostrigraphique de la marge occidentale de la plaque Caribe.- Mémoires de Géol. Lausanne, 20: 1-184.

DI MARCO, G., BAUMGARTNER, P.O \& CHANNELL, J.E.T., 1995: Late Cretaceous-early Tertiary paleomagnetic data and a revised tectonostratigraphic subdivision of Costa Rica and western Panama, in Geologic and Tectonic Development of the Caribbean Plate Boundary. In: Mann, P. (ed.) Geologic Tectonic Development of the Caribbean Plate Boundary in Southern Central America.- Spec. Pap. Geol. Soc. Am., 295: 1-29.

GARDNER, T.W., VERDONCK, N., PINTER, R., SLINGERLAND, K., FURLONG, T.F., BULLARD, F. \& Wells, S.G., 1992: Quaternary uplift astride the aseismic Cocos Ridge, coast of Costa Rica.- Geol Soc. Am. Bull. 104: 219-232.

GEIS, J.W., 1978: Biogenic Opal in three species of Gramineae.- An. Botany, 42: 1119-1129.

GRAF, M.T. \& CHMURA, G.L., 2006: Development of modern analogous for natural, mowed and grazed grasslands, using pollen assemblages and coprophilous fungi.- Rev. Palaeobot. Palynol. 141: 139-149.

GRILL, S.C. \& QUATROCCIO, M.E., 1996: Fluctuaciones eustáticas durante el Holoceno a partir de registro de paleomicroplancton: arroyo Naposta Grande, sur de la provincia de Buenos Aires.Ameghiniana, 33(4): 435-442.

GRINDROAD, J., 1985: The palynology of mangrove on a prograded shore. Princesa Charlotte Bay, north Queensland, Australia.- J. Biogeography, 12: 323-348.

GUY-OHLSON, D., 1992: Botryococcus as an aid in the interpretation of palaeoenviron- 
ment and depositional processes.- Rev. Palaeobot. Palynol. 71: 1-15.

ELSIK, W.C., 1976: Microscopic fungal remains and Cenozoic palynostratigraphy.Geoscience and Man, XV: 115-120.

FISHER, R.F., NEWELL, L.C. \& FISHER, W.F., 1995: Opal phytoliths as an indicator of the floristics of prehistoric grasslands.Geoderma, 68(4): 243-255.

FAEGRI, K. \& IVERSEN, J., 1975: Textbook of Pollen Analysis. - 295 p. Blackwell Scientific Publications. London.

HERNANDEZ, J.R., HENNEN, J.F., FARR, D.F., \& MCCRAY, E.B., 2007: Ravenelia. Online. Systematic Mycology and Microbiology Laboratory, ARS, USDA. Retrieved June 24, 2008, from http:// nt.ars-grin.gov/taxadescriptions/keys/ RaveneliaIndex.cfm

HOEK, C. VAN DEN; MANN, D.G. \& JAHNS, H.M., 1995: Algae: An introduction to phycology. -623 p. Cambridge University Press, XIV. Cambridge, United Kingdom.

HERRERA, S., 1985: Clima de Costa Rica.- 118 págs. EUNED. San José, Costa Rica.

HEY, R., 1977. Tectonic evolution of the CocosNazca spreading center.- Geol. Soc. Amer. Bull., 88: 1404-1420.

HORN, S., 1985: Estudio palinológico preliminar de dos núcleos cortos del Golfo Dulce, Costa Rica.- An. Esc. Nac. Cienc. Biol., Mex, 29: 57-70.

IBARAKI, M., 2002: Responses of planktonic foraminifera to emergence of the Isthmus of Panama.- Rev. Mex. de Cienc. Geol., 9(3): 152-160.

JARAMILLO, C. \& BAYÓNA, G., 2000: Mangrove distribution during the Holocene in Tribugá Gulf, Colombia.- Biotropica, 32(1): 14-22.
JARSEN, D.M. \& ELSIK, W.C., 1986: Fungal palynomorphs recovered from recent river deposits, Lungwa Valley, Zambia.Palynology, 10: 35-60.

KNOJA, T.M., LIVINGSTONE, D. \& WHITTON, B.A., 2007: Ecology of marine Rivularia population.- Hydrobiologia, 108(1): 65-73.

KOMÁREK, J. \& JANKOVSKÁ, V., 2001: Review of the green algal genus Pediastrum: implication for pollen-analytical research. -127 p. Berlin, Bibliotheca Phycologica, 108.

KOMÁREK, J. \& KOMÁRKOVÁLEGNEROVÁ, J., 2002: Contribution to the knowledge of planktic cyanoprokaryotes from Central Mexico.Preslia, 74: 207-233.

KONDO, R. \& SASE, T., 1986: Opal phytoliths, their nature and application.- Quat. Res. 25(1): 31-63.

LEW, L., 1983: The geology of the Osa Peninsula, Costa Rica: Observations and speculations of the outer arc of the Southern Central American orogen.- 128 págs. Penn. State University. [Thesis MSc.].

LIMAYE，R.B., KUMARAN，K.P.N., NAIR, K.M. \& PADMAIAI, D., 2007: Non-pollen palynomorphs as potential palaeoenvironmental indicators in the Late Quaternary sediments of the west coast of India.Current Science, 92(10): 1370-1382.

LONSDALE, P. \& KLITGORD, K.D., 1978: Structure and tectonic history of the eastern Panamá Basin.- Geol. Soc. Am. Bull., 81: 981-999.

LU, H. \& LIU, K., 2003: Phytoliths of common grasses in the coastal environments of southeastern USA.- Estuarine, Coastal and Shelf Science, 58: 587-600.

MCDOUGALL, K., 1996: Benthic foraminiferal response to emergence of the Isthmus of 
Panmáand coincident paleoceanographic changes.- Marine Micropaleontology, 28: 133-169.

MEDEANIC, S., 2006a: The palynomorphs from surface sediments of intertidal marshes in the estuarine part of the Patos Lagoon.Iheringia, sér. Botânica, 61(1-2): 49-62.

MEDEANIC, S., 2006b: Freshwater algal palynomorph records from Holocene deposits in the coastal plain of Rio Grande do Sul, Brazil.- Rev. Palaeobot. Palynol. 141: 83-101.

MEDEANIC, S., CORREAA, I.C.S. \& WESCHENFELDER, J., 2007: Palinomorfos nos sedimentos de fundo da laguna dos PatosRS: Aplicação nas reconstruções paleoembientais.- Gravel, 5: 89-102.

MEDEANIC, S., GARCIA, M.J. \& STEVAUX, J.C., 2004: A importância dos palinomorfos de fungos e de algas nas reconstruções paleoambientais: estudos em sedimentos superficiais da mata ripária do Alto Rio Paraná, Taquaruçu, MS.Revista de Geociências da Universidade de Guarulhos, 9 (6): 19-40.

PALS, J.P., VAN GEEL, B. \& DELFOS, A., 1980: Palaeoecological studies in the Klokkeweel bog near Hoogkarspel (Prov. of Noord-Holland).- Rev. Palaeobot. Palynol. 30: 371-418.

PANTIC, N. \& BAJAKTAREVIC, Z., 1988: Nannoforaminifera in palynological preparations and semar-slides from Mesozoic and Tertiary deposits in Central and Southeast Europe.- Revue de Paléobiologie, Benthos'86, special volume (2): 953-959.

PIPERNO, D.R., 1989: The occurrence of phytoliths in the reproductive structures of selected tropical angiosperm and their significance in tropical paleoecology, paleoethnobotany and systematics.- Rev. Palaeobot. Palynol. 61: 147-173.
PIPERNO, D.R., BUSH, M.B. \& \& COLINVAUX, P.A., 1990: Paleoenvironments and human occupation in late-glacial Panama.- Quat Res. 33: 108-116.

PIROZYNSKI, K.A., JARZEN, D.M., CARTER, A. \& DAY, R.G., 1988: Palynology and mycology of organic clay balls accompanying Mastodon Bonés- New Brunswick, Canada.- Grana, 27: 123-139.

PRAGER, A, BARTHELMES, M., THEUERKAUF, M. \& JOOSTEN, H., 2006: Non-pollen palynomorphs from modern Alder carrs and their potential for interpreting microfossil data from peat.Rev. Palaeobot. Palynol. 141(1-2): 7-32.

QUIRÓS, G., 2003: Circulación del Golfo Dulce: un fiordo tropical.- Top. Met. Ocean., 10(2): 75-83.

RICHARDS, F.A., ANDERSON, J.J. \& CLINE, J.D., 1971: Chemical and physical observations in Golfo Dulce, an anoxic basin at the Pacific coast of Costa Rica.- Limnol. Oceanog., 16: 43-50.

RIERA, S., LÓPEZ-SÁEZ, J.A. \& JULIÁ, R., 2006: Lake responses to historical land use changes in northern Spain: The contribution of non-pollen palynomorphs in a multiproxy study.- Rev. Palaeobot. Palynol. 141(1-2): 127-138.

RODGERS III, J.C. \& HORN, S., 1996: Modern pollen spectra from Costa Rica.Palaeogeography, Paleoclimatology, Palaeoecology, 124: 53-71.

RULL, V. \& VEGAS-VILARRÚBIA, T., 1999: Surface palynology of a small coastal basin from Venezuela and potential paleoecological applications.- Micropaleont. 45(4): 365-393.

SIMBERLOFF, D.S., 1983: Mangroves (mangles, mangroves).- In: D.H. JANZEN (ed.). Costa Rican Natural History. Univ. Chicago Press, 273-276. 
SMITHSON, F. 1956: Plant opal in soil.Nature, 178: 107.

STANCLIFFE, R.P., 1989: Microforaminiferal linings: their classification, biostratigraphy and paleoecology, with special reference to specimens from British Oxfordian sediments.- Micropaleontology, 5(4): 337-352.

SVENDSEN, H., ROSLAND, R., MYKINGL, S., VARGAS, J.A., LIZANO, O. \& ALFARO, E.J., 2006: A physical-oceanographic study of Golfo Dulce, Costa Rica.- Rev. Biol. Trop., 54 (1): 1-24.

TOMITANI,A., KNOLL,A.H., CAVANAUGH, C.M. \& OHNO, T., 2006: The evolutionary diversification of cyanobacteria: Molecular - phylogenetic and paleontological perspectives.- PNAS, 103(14): 5442-5447.

TOURNON, J.P., 1984: Magmatismes du mesozoique à l'actuel en Amerique Centrale: L'exemple de Costa Rica, des ophiolites aux andesites.- Sc. Terre, Univ. Curie, Paris, 84(49): 1-335.

TRAVERSE, A., 1988: Paleopalynology.- 600 p. Boston, Unwin Hyman.

VAN GEEL, B., 1976: Fossil spores of Zygnemataceae in ditches of a prehistoric settlement in Hoogkarspel (The Netherlands).- Rev. Palaeobot. Palynol. 22(4): 337-344.

VAN GEEL, B., 1986: Application of fungal and algal remains and other microfossils in palynological análisis.- In: BERGLUND, B.E.(ed): Handbook of Holocene Palaeoecology and Palaeohydrology. Wiley, Chichester, 497-505.

VAN GEEL, B., 2006. Quaternary non-pollen palynomorphs' deserve our attention.- Rev. Palaeobot. Palynol. 41(1-2): ii-viii.
VAN GEEL, B. \& APTROOT, A., 2006: Fossil ascomycetes in Quaternary deposits.- Nova Hedwigia, 82(3-4): 313-329.

VAN GEEL, B. \& VAN DER HAMMEN, T., 1978: Zygnemataceae in Quaternary Colombian sediments.- Rev. Palaeobot. Palynol. 25(5): 377-392.

VAN GEEL, B., MUR, L.R., RALSKAJASIEWICZOWA, M. \& GOSLAR, T., 1994: Fossil akinetes of Aphanizomenon and Anabaena, as indicators for medieval phosphate-eutrophication of Lake Gosciaz (Central Poland).- Rev. Palaeobot. Palynol. 83: 97-105.

VAN VEEN, F.R., 1957: Microforaminifera.Micropaleontology, 3(1): 74-74.

VANNUCCHI, P., FISHER, D.M., BIER, S.P. \& GARDNER, T.W., 2006: From seamount accretion to tectonic erosion: Formation of Osa Mélange and the effects of Cocos Ridge subduction in southern Costa Rica.- Tectonics, 25: TC2004.

WILSON, D.S. \& HEY, R.N., 1981: The Galapagos axial magnetic anomaly: Evidence for the Emperor event within the Bruhnes and for a two-layer magnetic source.- Geophys. Res. Lett., 8: 167-188.

WILSON, L.R. \& HOFFMEISTER, W.S., 1952: Small foraminifera.- The Micropaleontologist, 6(2): 26-28.

WHITTON, B.A. \& POTTS, M., 2000: Introduction to the cyanobacteria.- In Whitton, B.A. \& Potts, M. (eds.): The Ecology of Cyanobacteria. Their diversity in Time and Space.- Kluwer Academic Publishers, the Netherlands, 1-10. 
ZAMORA, N., MEDEANIC, S., \& CORRÊA, I.C.S., 2007a: Microforaminíferos como indicadores paleoambientais: estudo palinológico na região sul da Costa Rica, América Central.- Gravel, 5: 75-87.
ZAMORA, N., MEDEANIC, S. \& CORREA, I.C.S., 2007b: Dados granulométricos e palinológicos dos sedimentos pliocênicos e quaternários da região de Puerto Jimenez, sudeste da Costa Rica.- In: IX Congresso da Associação Brasileira de Estudos do Quaternário (Anais), Belém. 


\section{PLATE I}

Algal palynomorphs and cyanobacteria:

1 -Botryococcus, 2, 3 -Spirogyra, 4-Mougeotia, 5-Pseudoschizaea, 6-Spirulina, 7 -Rivularia, 8 - unidentified, 9 - unidentified, 10 - Anabaena?

Scale: $10 \mu \mathrm{m}$. 


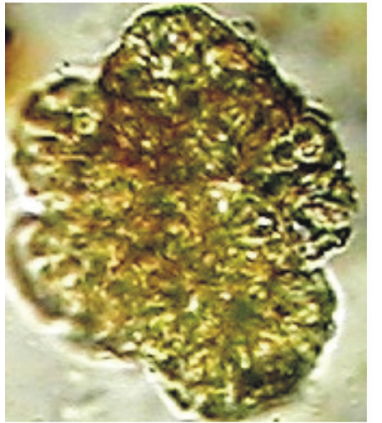

1

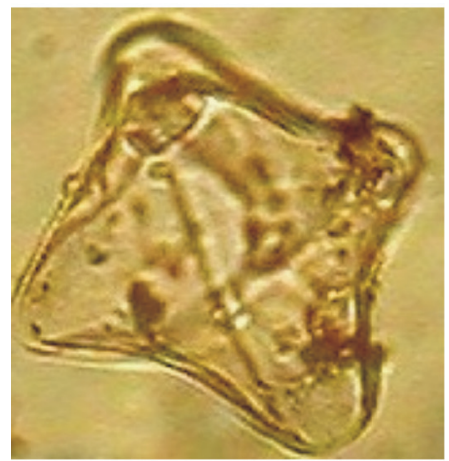

4
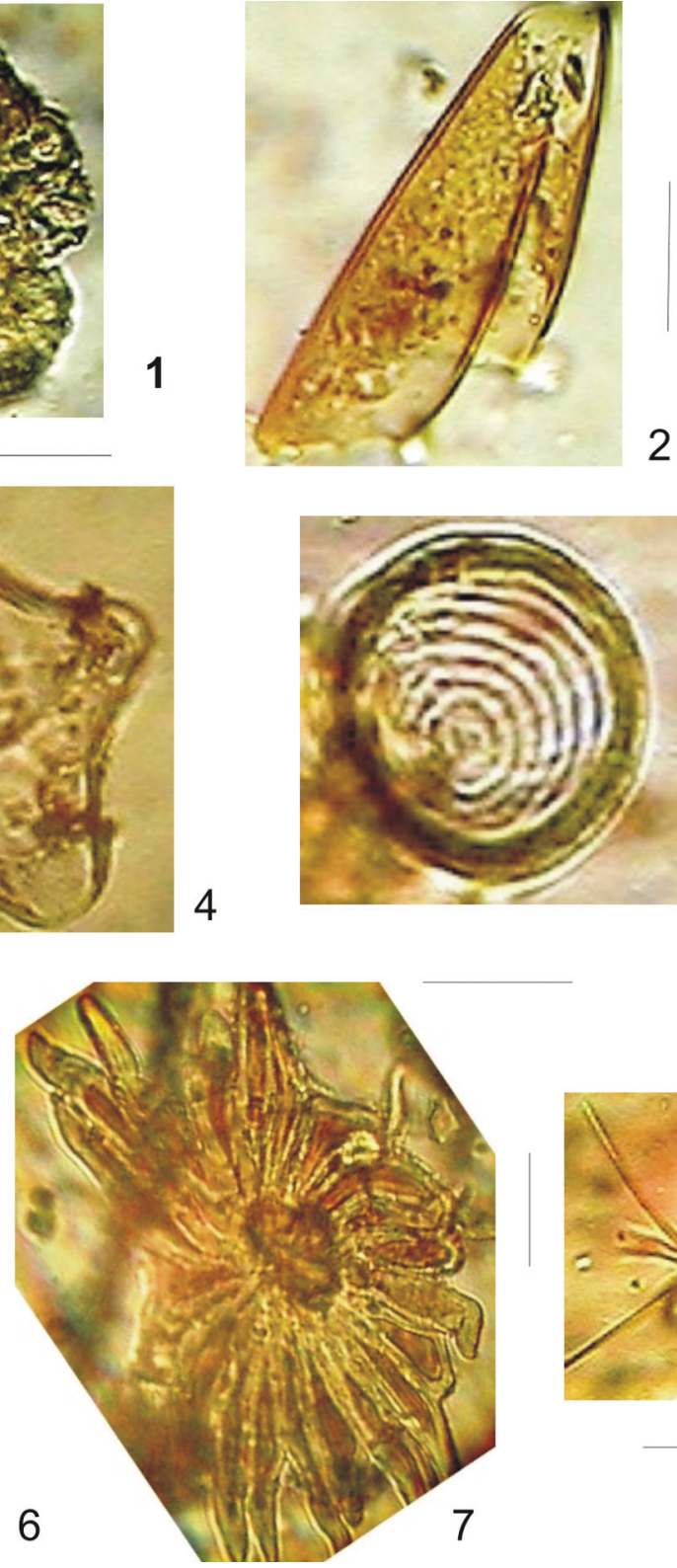

2

5

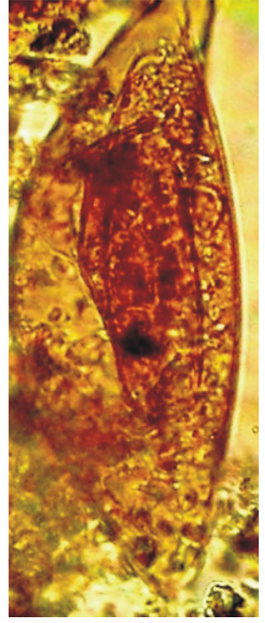

3
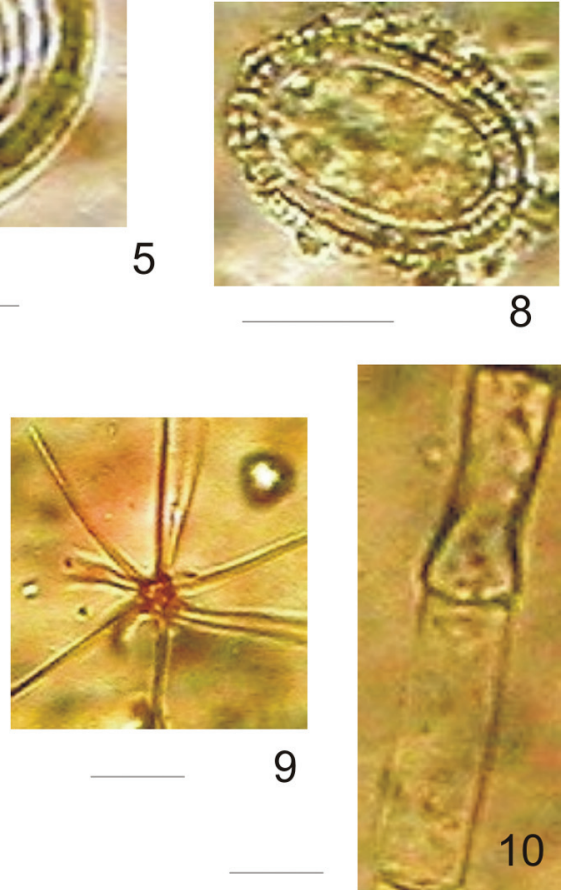


\section{PLATE II}

Fungal palynomorphs:

1-3 - Glomus, 4 - Diporisporites, 5,6 - type A (unidentified), 7 - Polyadosporites, 8,9 - Tetraploa, 10 - type $B$ (unidentified), 11 - hyphae, 12 - unidentified.

Scale: $20 \mu \mathrm{m}$. 

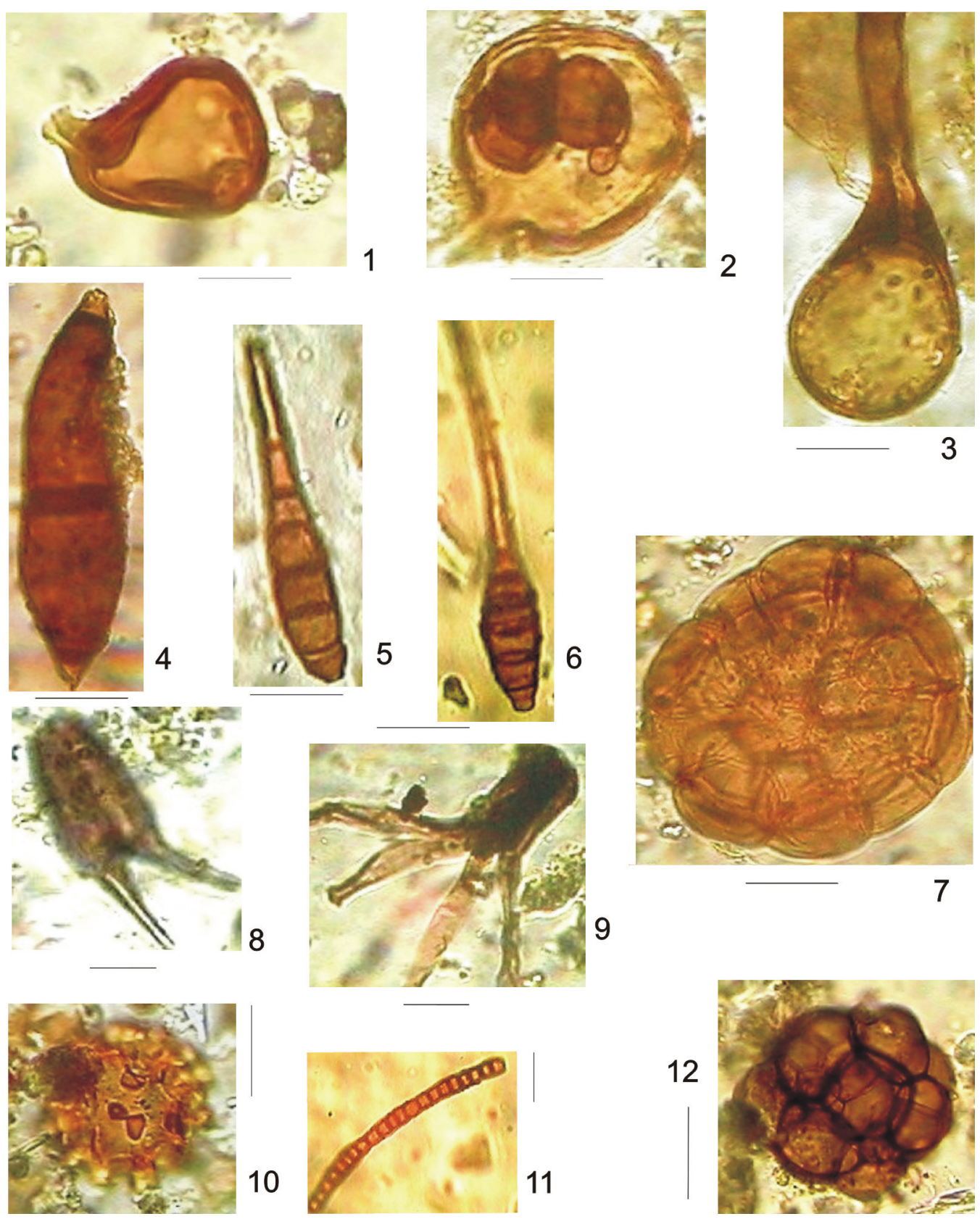


\section{PLATE III}

Phytoliths, scolecodonts and microforaminifers:

1-5 - phytoliths, 6,7 - scolecodonts, 8,9-microforaminifera.

Scale: $10 \mu \mathrm{m}$. 

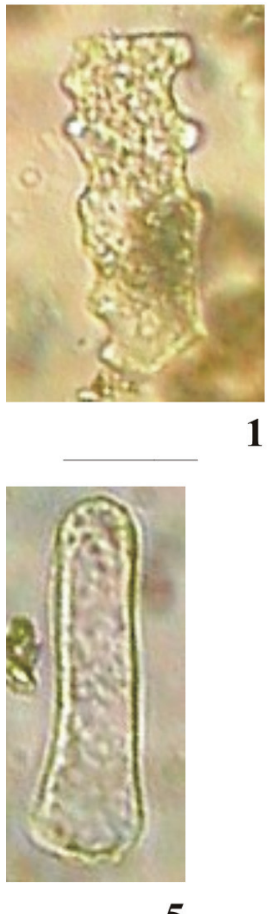

5

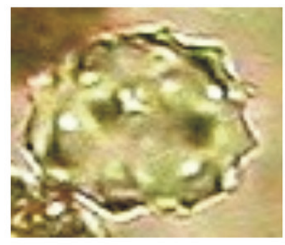

2

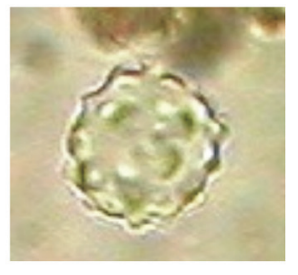

3

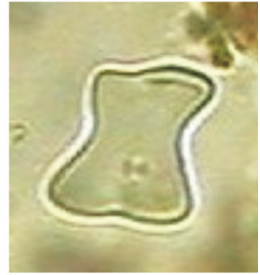

4
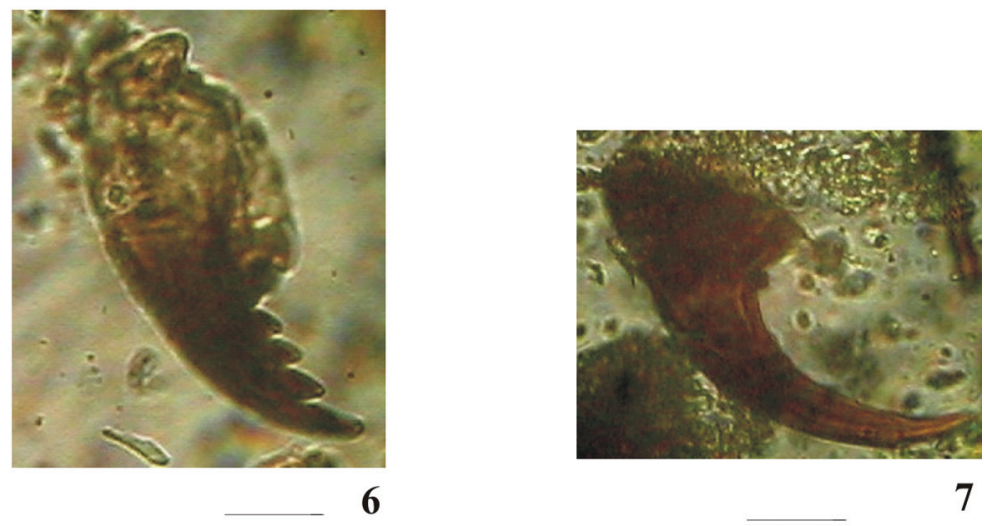

6

7

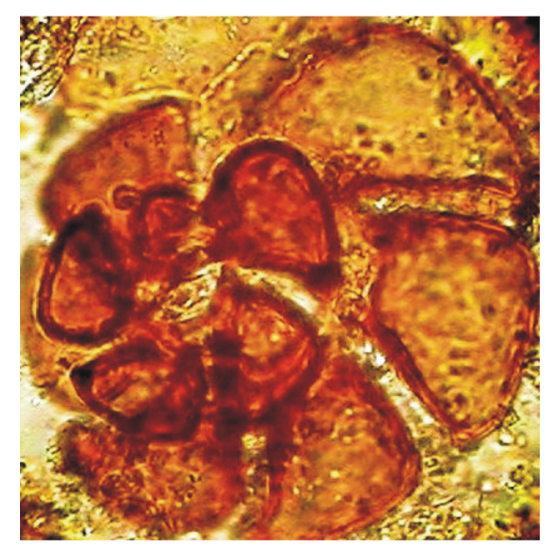

8

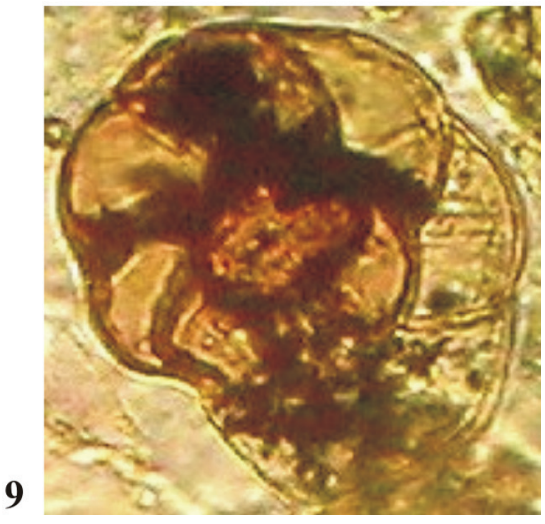


